\title{
JA $A$
}

\section{Journal of}

A GRICULTURAL

and APPLIED

ECONOMICS

ISSN $\quad 1074-0708$

Volume 53 | Number 1 | February 2021



CAMBRIDGE UNIVERSITY PRESS 


\title{
Journal of Agricultural and Applied Economics
}

\author{
EDITORS \\ Carlos Carpio \\ Texas Tech University \\ Olga Isengildina Massa \\ Virginia Polytechnic Institute and State University \\ David Willis \\ Clemson University
}

\section{EDITORIAL COUNCIL}

Bustanul Arifin

University of Lampung, Indonesia

Christopher Boyer

University of Tennessee

Bo Chen

Huazhong Agricultural University,

China

Sheldon Du

University of Wisconsin-Madison

Mariah Ehmke

University of Wyoming

Xiaoli Etienne

West Virginia University

Pan Fanghui

Northeast Agricultural University, China

Matthew Fannin

Louisiana State University

Julieta Frank

University of Manitoba, Canada

Thomas Glauben

University of Halle, Germany

Valentina Hartarska

Auburn University
Vardges Hovhannisyan

University of Wyoming

David Hughes

University of Tennessee - Knoxville

Songqing Jin

Michigan State University

Samerandu Mohanty

International Potato Center, Vietnam

George Norton

Virginia Tech

Gokhan Ozertan

Bogazici University, Turkey

Dustin Pendell

Kansas State University

Jeffrey Reimer

Oregon State University

Jill Stowe

University of Kentucky

Alcido Elenor Wander

Brazilian Agricultural Research

Corporation, Brazil

Wei Zhang

Virginia Tech 


\section{Journal of Agricultural and Applied Economics}

\begin{tabular}{lll}
\hline Volume 53 & February 2021 & Number 1 \\
\hline
\end{tabular}

\section{RESEARCH ARTICLES}

Spatially Mediated Peer Effects in the Adoption of Conservation Agriculture Practices DEEPTHI KOLADY, WEIWEI ZHANG, TONG WANG AND JESSICA ULRICH-SCHAD

A Tournament Approach to Price Discovery in the U.S. Cattle Market

JEFFREY WRIGHT, MAN-KEUN KIM, HERNAN A. TEJEDA AND HWA-NEYON KIM

Sounds Better? Potential Implications of Obscure American Viticultural

Areas to Consumers

KAR H. LIM

The Influence of State-Level Production Outcomes upon U.S. National Corn and Soybean Production: A Novel Application of Correlated Component Regression

DAVID W. BULLOCK

Management of Multiple Sources of Risk in Livestock Production

MELISSA G.S. MCKENDREE, GLYNN T. TONSOR AND LEE L. SCHULZ

COVID-19's Impact on Farmers Market Sales in the Washington, D.C., Area

JEFFREY K. O'HARA, TIMOTHY A. WOODS, NONY DUTTON

AND NICK STAVELY

Factors Impacting Reproductive Success and Asset Value of Beef Breeding Females in Mississippi Auctions

TORI L. MARSHALL, KALYN T. COATNEY, JANE A. PARISH, RANDALL D. LITTLE, JOSH G. MAPLES AND BRIAN R. WILLIAMS

The Economics and Productivity of Organic versus Conventional U.S. Dairy Farms RICHARD F. NEHRING, JEFFREY GILLESPIE, CATHERINE GREENE AND JONATHAN LAW

Effects of Ad-hoc Data Truncation and Homogeneous Preferences on Recreational Demand and Values: An Application to the George Washington and Jefferson National Forests

KAVITA SARDANA, JOHN C. BERGSTROM AND J. M. BOWKER 